\title{
Assessment of the Needs of People With Multiple Sclerosis in Khuzestan Province, 2015
}

\author{
Shahin Gohar Pey ${ }^{*}$, Fateme Esfandiarpour¹, Zohreh Kahed ${ }^{2}$, Mohammad Hossein Haghighi Zade ${ }^{3}$
}

1. Department of Physical Therapy, Musculoskeletal Rehabilitation Research Center, Ahvaz Jundishapur University of Medical Sciences, Ahvaz, Iran 2. Department of Rehabilitation Administration, Musculoskeletal Rehabilitation Research Center, Ahvaz Jundishapur University of Medical Sciences, Ahvaz, Iran

3. Department of Statistics and Epidemiology, Faculty of Health, Ahvaz Jundishapur University of Medical Sciences, Ahvaz, Iran.

Cttation: Gohar Pey Sh, Esfandiarpour F, Kahed Z, Haghighi Zade MH. Assessment of the Needs of People With Multiple Sclerosis in Khuzestan Province, 2015. Iranian Rehabilitation Journal. 2016; 14(3):163-170. https://doi.org/10.18869/nrip.irj.14.3.163

https://doi.org/10.18869/nrip.irj.14.3.163

Article info:

Received: 04 jan. 2016

Accepted: 29 May 2016

\section{Keywords:}

Needs assessment, Multiple sclerosis, Southampton questionnaire, Khuzestan, Iran

\section{ABSTRACT}

Objectives: The aim of this study was to determine the type and priority needs of people with multiple sclerosis in Khuzestan using Persian version of the Southampton Needs Assessment Questionnaire (SNAQ) and their relationship to age, gender, and physical disability scale, respectively.

Methods: In this cross-sectional study, the priority needs of 100 patients with multiple sclerosis (aged below 18 years) were studied, whose diagnosis had crossed over a period of one year. This study was covered by the MS Society of Khuzestan Province. Out of 100 patients, 25 were men and 75 were women. The data were analyzed to calculate the dispersion index of the unmet needs after the determination of initial priority needs by using the chi-square statistics.

Results: Based on the patients' responses, around eight unmet needs were located. Treatment needs, rehabilitation, and financial assistance were the first priority, the need for affordable housing and optimizing environment were at the second place, and employment, information, and fun were at the third place. With the increasing scale of physical disability, the dependence of the individuals on basic needs like treatment, rehabilitation, financial service and, accessibility for an optimizing environmental increases, and people's satisfaction with the quality of health services reduces $(\mathrm{P}<0.05)$. The findings of the study also highlighted that need for information increases with increase in age $(\mathrm{P}<0.05)$.

Discussion: In order to meet the needs of people with multiple sclerosis in Khuzestan province, attempts should be made by planners and authorities to fix the therapeutic, rehabilitation, and financial issues at first, followed by the issues of affordable housing. Appropriate measures should be implemented for the success of these programs, and proper assessments of its functionality should be done in a periodic manner. 


\section{Introduction}

D

isability affects both the individuals and society. Rehabilitation is the only phenomenon that can serve as a response to the needs of the individual and society [1]. Research works have suggested that policy makers and professional therapists should identify and consider the needs of the patients while planning the developmental interventions as it would result in the better participation of patients during the rehabilitation process [2]. Without a proper assessment, it is not possible to reschedule the program objectives, allocate resources, and provide appropriate methods to meet the needs of the patient [3]. Some studies indicate that there is a relationship between the high number of unmet needs and the low quality of life [5].

Multiple sclerosis (MS) is one of the most common causes of disability in chronic neurological disorders found in the middle-aged adults, especially in individuals between 1059 years of age. About 75 percent of people are within the age group of 25-30 years [6]. According to the MS Society of Iran, the number of people with MS is around 70 thousand, whereas it is 1764 according to the MS Society of Khuzestan province [7]. Given the incremental trend of multiple sclerosis along with large expenditures and incidences of both physical and mental problems, providing the patients with an efficient and timely rehabilitative care is one of the important priority needs [8].

As MS progresses, it can majorly disrupt the patient's career, social, and family life [6]. A simultaneous balance between the needs assessment and planning followed by appropriate action can improve the patient's quality of life [9]. As a part of the key elements of high-quality treatment, the healthcare centers have started treating the MS patients as normal people [10]. Studies have been carried out to compare the perception of treatment by caregivers and physicians for patients with MS; they have reported a great mismatch between their perceptions.

In Iran, not much research has been done to examine the rehabilitation needs of patients with MS. A qualitative study on the needs of patients and their families has been investigated by Hamadan [12]. Another study has focused on the training provided for needs assessment of patients with MS in Tehran $[13,17]$. To the best of our knowledge, there are no studies assessing the needs of patients with MS in Khuzestan. According to the causes and factors affecting the incidences of MS, as genetic, geographical conditions, and environmental factors in the assessment of confounding factors determining the rehabilitation needs of MS patients in Khuzestan is nec- essary; Confounding factors such as time, location, economic, cultural and individual needs.

\section{Methods}

The population of this cross-sectional study comprised of people with MS ( $<18$ years). They had records in the MS Society of Khuzestan province after using its services for at least one year from the time of diagnosis. The MS patients with disabilities like blindness, deafness, and spinal cord injury were excluded. Out of 1764 patients registered in 1994 under the MS Society of Khuzestan province, 100 were randomly selected on the basis of their medical records in consideration with the inclusion and exclusion criteria of the study.

The research was conducted by using the Persian version of Southampton Needs Assessment Questionnaire (SNAQ) [14], which was devised to determine the needs of people with physical-motor disabilities. The data was analyzed by using chi-square statistics, and the distribution indicators of unmet needs were calculated after determining the priority needs of the MS patients. After providing all the necessary information about the study, the participants were asked to sign the consent forms approved by the Ethics Committee of the Medical University of Ahvaz, and were not imposed with any participation fee.

\section{Results}

According to the software-based output results and data analysis, $75 \%$ of participants scored between $1.5-4.5$, and $25 \%$ scored 5-8.5 on the Expanded Disability Status Scale (EDSS). The Pearson Correlation Coefficient (r) of the disability amount between the health services and rehabilitation needs were obtained as -0.24 and 0.02 , respectively $(\mathrm{P}=0.05)$. In general, $66 \%$ of study population expressed the need for housing. According to EDSS and Pearson's chi-square test statistic value, the relationship between participant's housing need and physical disability $(82.12=2 \mathrm{X}$ with 3 degrees of freedom; $P>0.05$ ) was approved, whereas the supposed null hypothesis $(\mathrm{H} 0)$ was rejected (Table 1).

The relationship between the items needed to make a house suitable for the MS patients with respect to their age was calculated, and change in the order of $\mathrm{X}^{2}, 16.42$ and 10.08 with 3 degrees of freedom $(\mathrm{P}<0.05)$ was obtained (Table 2$)$. The relationship between the home decor items and variable age of participants was confirmed, and the supposed $\mathrm{H} 0$ was rejected.

On examining the health needs and gender, the relationship on the basis of the need for recreational craft activities (such as painting and making flowers, etc.), computer, and 
Table 1. Relationship between housing need with severity of disability based on EDSS.

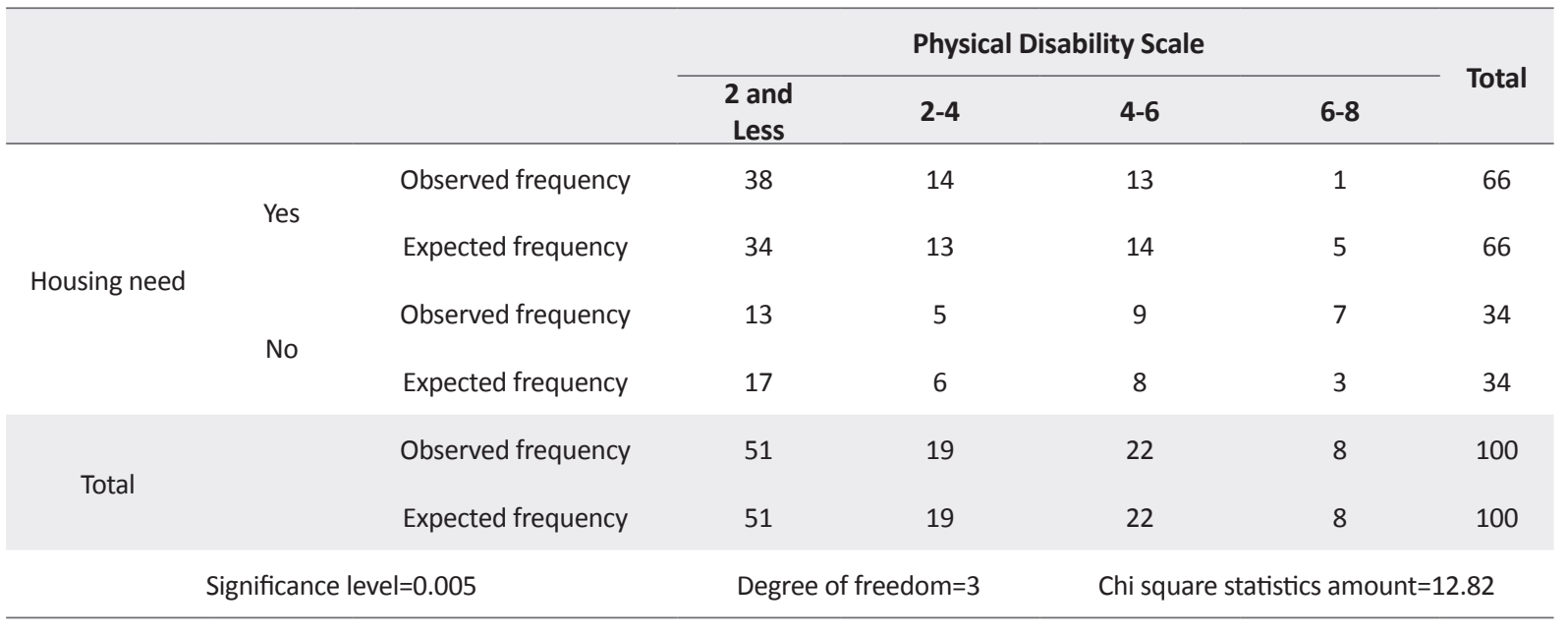

Ilranian Rehabilitation \ournal

intellectual tasks in order of $\mathrm{X}^{2}, 5.52,5.47$, and 5.42 with 1 degree of freedom $(\mathrm{P}<0.05)$, respectively was confirmed; whereas the supposed $\mathrm{H} 0$ was rejected (Table 3 ).

The relationship between the information needs and age, based on the variables of the need for information using the
Pearson's chi-square test value $\left(\mathrm{X}^{2}=6.57\right)$ and 2 degrees of freedom $(\mathrm{P}<0.05)$, respectively was confirmed. However, the supposed H0 was rejected (Table 4).

According to EDSS statistics, the relationship between Information needs need and severity of disability, based

Table 2. Relationship between the items needed to make a house suitable according to age.

\begin{tabular}{|c|c|c|c|c|c|c|c|c|c|c|c|c|}
\hline \multirow{3}{*}{$\begin{array}{l}\text { Items of the } \\
\text { Need of Making } \\
\text { Appropriate }\end{array}$} & \multicolumn{9}{|c|}{ Respondent's Age } & \multirow{2}{*}{\multicolumn{3}{|c|}{ Bivariate Chi-Square Test }} \\
\hline & \multicolumn{3}{|c|}{$\begin{array}{c}\text { Less Than } 30 \text { Years } \\
\text { Old }\end{array}$} & \multicolumn{3}{|c|}{ 30-50 Years Old } & \multicolumn{3}{|c|}{ 50-70 Years Old } & & & \\
\hline & Yes & No & Total & Yes & No & Total & Yes & No & Total & Value & df & Sig. \\
\hline $\begin{array}{l}\text { Need to make } \\
\text { housing appropri- } \\
\text { ate }\end{array}$ & 18 & 20 & 38 & 19 & 10 & 29 & 3 & 2 & 5 & 2.24 & 2 & 0.33 \\
\hline $\begin{array}{l}\text { The need to } \\
\text { promote safety }\end{array}$ & 6 & 31 & 37 & 17 & 12 & 29 & 4 & 1 & 5 & 16.42 & 2 & $* 0.00$ \\
\hline Decor change & 12 & 27 & 39 & 20 & 11 & 31 & 4 & 1 & 5 & 10.08 & 2 & $* 0.01$ \\
\hline $\begin{array}{l}\text { To help access } \\
\text { home }\end{array}$ & 8 & 31 & 39 & 12 & 18 & 30 & 2 & 2 & 4 & 3.85 & 2 & 0.15 \\
\hline $\begin{array}{l}\text { The need for } \\
\text { change home }\end{array}$ & 11 & 27 & 38 & 18 & 15 & 33 & 2 & 3 & 5 & 4.79 & 2 & 0.09 \\
\hline $\begin{array}{l}\text { Previous at- } \\
\text { tempts to } \\
\text { improve home }\end{array}$ & 6 & 40 & 46 & 5 & 32 & 37 & 1 & 4 & 5 & 0.18 & 2 & 0.91 \\
\hline $\begin{array}{c}\text { Need to light } \\
\text { handheld wheel- } \\
\text { chair }\end{array}$ & 1 & 18 & 19 & 6 & 11 & 17 & 0 & 2 & 2 & 5.86 & 2 & $* 0.05$ \\
\hline $\begin{array}{c}\text { Need to a static } \\
\text { wheelchair }\end{array}$ & 0 & 18 & 18 & 2 & 12 & 14 & 1 & 1 & 2 & 6.42 & 2 & $* 0.02$ \\
\hline $\begin{array}{l}\text { Need to a stretch- } \\
\text { er wheelchair }\end{array}$ & 0 & 18 & 18 & 2 & 12 & 14 & 1 & 1 & 2 & 6.43 & 2 & ${ }^{*} 0.03$ \\
\hline
\end{tabular}


Table 3. Relationship between the need for recreation and gender.

\begin{tabular}{|c|c|c|c|c|c|c|c|c|c|}
\hline \multirow{3}{*}{$\begin{array}{l}\text { Items of the Need } \\
\text { of Recreation and } \\
\text { Leisure Time }\end{array}$} & \multicolumn{6}{|c|}{ Gender } & \multicolumn{3}{|c|}{ Bivariate Chi-Square Test } \\
\hline & \multicolumn{3}{|c|}{ Male } & \multicolumn{3}{|c|}{ Female } & \multirow[b]{2}{*}{ Value } & \multirow[b]{2}{*}{ df } & \multirow[b]{2}{*}{ Sig. } \\
\hline & Yes & No & Total & Yes & No & Total & & & \\
\hline $\begin{array}{l}\text { Watching } T V \text {, listening to } \\
\text { radio and music }\end{array}$ & 25 & 0 & 25 & 60 & 10 & 70 & 3.99 & 1 & 0.05 \\
\hline $\begin{array}{l}\text { Reading book, maga- } \\
\text { zine, newspaper }\end{array}$ & 12 & 9 & 21 & 25 & 36 & 61 & 1.65 & 1 & 0.20 \\
\hline Handcrafts & 1 & 20 & 21 & 18 & 42 & 60 & 5.52 & 1 & 0.02 \\
\hline Party & 16 & 6 & 22 & 38 & 28 & 66 & 1.60 & 1 & 0.21 \\
\hline $\begin{array}{l}\text { Going to park mountain } \\
\text { and traveling }\end{array}$ & 6 & 15 & 21 & 31 & 34 & 65 & 2.37 & 1 & 0.12 \\
\hline Cinema & 3 & 18 & 21 & 9 & 52 & 61 & 0.00 & 1 & 0.96 \\
\hline Sport & 8 & 15 & 23 & 32 & 34 & 66 & 1.29 & 1 & 0.25 \\
\hline $\begin{array}{l}\text { Playing music instru- } \\
\text { ments }\end{array}$ & 1 & 20 & 21 & 7 & 52 & 59 & 0.87 & 1 & 0.35 \\
\hline Computer & 11 & 10 & 21 & 15 & 46 & 61 & 5.57 & 1 & 0.02 \\
\hline Chess and brain teaser & 7 & 16 & 23 & 6 & 55 & 61 & 5.42 & 1 & 0.02 \\
\hline
\end{tabular}

Iranian Rehabilitation \ournal

Table 4. Relationship between the information needs and age.

\begin{tabular}{|c|c|c|c|c|c|c|c|c|c|c|c|c|}
\hline \multirow{3}{*}{$\begin{array}{l}\text { Items of the Need } \\
\text { of Information }\end{array}$} & \multicolumn{9}{|c|}{ Respondent's Age } & \multirow{2}{*}{\multicolumn{3}{|c|}{ Bivariate Chi-Square Test }} \\
\hline & \multicolumn{3}{|c|}{$\begin{array}{c}\text { Less Than } 30 \text { Years } \\
\text { Old }\end{array}$} & \multicolumn{3}{|c|}{$30-50$ Years Old } & \multicolumn{3}{|c|}{ 50-70 Years Old } & & & \\
\hline & Yes & No & Total & Yes & No & Total & Yes & No & Total & Value & df & Sig. \\
\hline $\begin{array}{l}\text { Information of the } \\
\text { following actions of } \\
\text { the disease }\end{array}$ & 32 & 12 & 44 & 32 & 10 & 43 & 1 & 4 & 5 & 6.57 & 2 & 0.04 \\
\hline $\begin{array}{l}\text { Information regard- } \\
\text { ing medications and } \\
\text { treatments needed }\end{array}$ & 34 & 9 & 43 & 32 & 12 & 41 & 2 & 3 & 5 & 3.90 & 2 & 0.14 \\
\hline $\begin{array}{c}\text { Assistance and } \\
\text { advice service loca- } \\
\text { tions }\end{array}$ & 27 & 18 & 45 & 28 & 11 & 41 & 4 & 1 & 5 & 1.18 & 2 & 0.55 \\
\hline Home modifications & 29 & 17 & 46 & 28 & 18 & 41 & 3 & 2 & 5 & 0.33 & 2 & 0.85 \\
\hline Labor rights & 34 & 9 & 43 & 30 & 32 & 40 & 4 & 1 & 5 & 0.22 & 2 & 0.90 \\
\hline
\end{tabular}


Table 5. Relationship between the information needs with severity of disability variable based on EDSS scale.

\begin{tabular}{|c|c|c|c|c|c|c|c|c|c|c|c|c|c|c|c|}
\hline \multirow{3}{*}{$\begin{array}{l}\text { Items of } \\
\text { Information } \\
\text { Needed }\end{array}$} & \multicolumn{12}{|c|}{ Physical Disability Scale } & \multirow{2}{*}{\multicolumn{3}{|c|}{$\begin{array}{l}\text { Bivariate Chi- } \\
\text { Square Test }\end{array}$}} \\
\hline & \multicolumn{3}{|c|}{2 and Less } & \multicolumn{3}{|c|}{$2-4$} & \multicolumn{3}{|c|}{ 4-6 } & \multicolumn{3}{|c|}{$6-8$} & & & \\
\hline & Yes & No & Total & Yes & No & Total & Yes & No & Total & Yes & No & Total & Value & df & Sig. \\
\hline $\begin{array}{l}\text { Information } \\
\text { of following } \\
\text { actions of the } \\
\text { disease }\end{array}$ & 31 & 16 & 47 & 13 & 6 & 19 & 15 & 7 & 22 & 7 & 1 & 8 & 1.48 & 3 & 0.69 \\
\hline $\begin{array}{l}\text { Information } \\
\text { regarding } \\
\text { medications } \\
\text { and treatments } \\
\text { needed }\end{array}$ & 30 & 14 & 44 & 15 & 3 & 18 & 17 & 5 & 22 & 8 & 0 & 8 & 4.56 & 3 & 0.21 \\
\hline $\begin{array}{l}\text { Assistance and } \\
\text { advice service } \\
\text { locations }\end{array}$ & 29 & 18 & 47 & 13 & 5 & 18 & 13 & 9 & 22 & 8 & 0 & 8 & 5.30 & 3 & 0.15 \\
\hline $\begin{array}{l}\text { Home modifi- } \\
\text { cations }\end{array}$ & 25 & 23 & 48 & 16 & 2 & 18 & 14 & 8 & 22 & 8 & 0 & 8 & 12.44 & 3 & 0.01 \\
\hline Labor rights & 33 & 12 & 45 & 15 & 3 & 18 & 16 & 5 & 21 & 6 & 1 & 7 & 1.05 & 3 & 0.79 \\
\hline
\end{tabular}

Iranian Rehabilitation Journal

on Pearson Chi-square test statistic value $(X=44.12)$ with 3 degrees of freedom $(\mathrm{P}<0.05)$, was confirmed. On the other hand, the assumption of the $\mathrm{H} 0$ was rejected (Table 5).

The unmet priority needs of patients with multiple sclerosis were determined and ranked in accordance with their health care, rehabilitation, and financial priority needs (Table 6).

\section{Discussion}

The EDSS score increases with the increase in the individuals' dependency on the treatment services like health, rehabilitation, and finance. The increase in the inability to work or continue the job will increase the priority needs and costs of the primary health care and rehabilitation services for MS people, thereby, increas-

Table 6. Ranking of the unmet priority needs of patients with multiple sclerosis.

\begin{tabular}{ccccc}
\hline & \multicolumn{3}{c}{ Component } \\
\cline { 2 - 4 } & $\mathbf{1}$ & $\mathbf{2}$ & $\mathbf{3}$ & $\mathbf{4}$ \\
\hline Medical and rehabilitation needs & 0.92 & & \\
Financial need & 0.91 & 0.89 \\
Making suitable need & 0.60 & 0.89 \\
Housing needs & 0.66 & 0.57 & \\
Communication needs & & 0.58 & 0.56 \\
\hline Information need & & & \\
Other & & & \\
\hline
\end{tabular}


ing the individual's financial needs. The studies conducted overseas supported the findings of the present study because of the debilitating chronic nature of the disease. The scores of patients' priority needs were high on EDSS scale with the rise in the dependency on the primary health care and rehabilitation. The interdisciplinary rehabilitation models, instead of multidisciplinary ones, are more common in Iran that help in meeting the priority needs of the MS patients to some extent [15].

There was a significant correlation between the ageappropriate needs of patients with MS, which included the need to change the decor, for the promotion of safety, and disability-based wheelchairs. There was also a significant correlation between the appropriate priority need and the EDSS score, i.e. the increase in the EDSS score resulted in the increased need for making an appropriate priority need and peripheral access for daily activities and social participation. In this study, $51 \%$ of the subjects stated their need for an appropriate home. They also expressed their dissatisfaction that only $13 \%$ of actions have been taken to fulfill the needs.

The lack of information and appropriate measures to solve the problems has resulted in the poor standard of the rehabilitation programs in the city of Ahvaz. Developing ramps on sidewalks, lifts in multi-storey buildings, appropriate sidewalks, public transportation for disabled people in collaboration with the MS Society in Iran and other associations of physical-motor disabilities can help in improving the situation.

The recreational and leisure needs of the participants were different. The women subjects had hobbies such as painting, crafts, and going to parties, whereas the men subjects preferred chess, working with computers, and watching television. The patients stated that the problems caused by the disease along with the lack of financial need, appropriate environmental access, and transportation services result in fewer activities, such as cinema, traveling, playing games and sports, etc.

Studies have stated that men are competitive in their recreational motives as they aim to improve their physical conditions. Comparatively, women are more motivated toward social participation [16]. Therefore, the MS Society and other welfare organizations such as municipalities should plan the recreational activities to reduce the psychological stress of the disease on patients and improve their physical abilities by creating appropriate public places and buildings and providing peripheral access. Awareness on the problems, needs, and solutions should be spread among the community, family of the
MS patients, and the policy makers to help the patients meet these requirements.

There is a direct correlation between the need for meaningful information and age, i.e. both the parameters are directly proportional to each other. Similarly, there is also a relationship between the need for information and EDSS score. The need for information increases with increase in the scale statistics. Prior studies are consistent with the findings of this research [17]. According to these experts and associations related to multiple sclerosis patients as well as for the information media, the effectiveness and efficiency awareness and giving information to patients walk.

The present study also showcased that treatment, rehabilitation needs, and financial helps are the first priority needs of people with MS; the need for housing in the second place, and need for appropriate environment, and other factors like communication and information, etc. in the third place. Previous studies in Iran and other countries have confirmed about the relationship between the needs of patients and the geographical, cultural, social, financial, and physical conditions

In another study by Forbs et al, the priority needs of patients in London were found to be related to the medical, social, biological, adjustmental needs [17]. Baraheni et al. (2014) in Italy found that qualified supervisors and specialists along with MS people had high priority needs for information and access to services [18]. In Canada, Koopmans et al. (2003) reviewed a group of patients with severe MS with a group of professionals, caregivers, and family members and found them to be different in priority needs in finance and information [16].

Abolhasani et al. (2014) arranged the priority needs of the MS patients in three groups as per the viewpoints of the families of the patients and service providers. The first group included the empowerment of patients by providing required treatments, raising awareness, and self-confidence against the disability. On the other hand, the second group comprised of empowerment of family members of MS patients in terms of psychological comfort and awareness, economic security, reducing cost, and organizational support. Finally, in the third group, the spiritual need encompassed compatibility and comfort. The study expressed the needs of patients from the perspective of caregivers and specialists of the patients with MS. their own vision of has been considered we Note although the presence of provincial differences in the two study despite the differences and similarities of the subjects still be seen in the results. 


\section{Conclusion}

Conclusively, both therapy and financial needs are expressed as priority needs for rehabilitation program [12]. However, the priority needs in the overseas studies were expressed in terms of home care, preserving the role of the patient and their family in the society, and independence in daily activities. These differences could be due to the lack of attention and appropriate priority needs of patients, i.e. financial support treatment, housing, and rehabilitation provided to the people with MS in Iran.

This study has proposed that future investigation on the needs assessment of the patients with MS should be conducted in comparison with other provinces.

\section{Acknowledgements}

This article is extracted from a thesis for the degree of Master of Rehabilitation Management of Mrs. Zohreh Kahed, a student at the University of Medical Sciences Ahvaz. (Numbering project: pht-9421). We are grateful to the Vice Chancellor for Research and Technology Development, Ahvaz University of Medical Sciences, for financial support for this project. We also appreciate the MS Society of Khuzestan. We are thankful to Mrs. N. Majdinasab for her cooperation in conducting this study.

\section{Conflict of Interest}

The authors declared no conflict of interests.

\section{References}

[1] Karimi Dormani H. [Rehabilitation of certain groups (Persian)]. $1^{\text {st }}$ ed. Tehran: Roshd; 2011.

[2] Gough L. Economic institutions and the satisfaction of human needs. Journal of Economic Issues. 1994; 28(1):25-66.

[3] Petersen DJ, Alexander GR. Needs assessment in public health. A practical Guide for students and professionals. Oxford: Springer; 2002.

[4] Swain J, French S, Cameron C. Controversial issues in a disabling society. Oxford: MC Graw-Hill International; 2003.

[5] Slade M, Leese M, Rugeri M, Kuipers E, Tansella M, Thornicroft G. Dose meeting needs improve quality of life. Psychotherapy \& Psychosomatics. 2004; 73(3):183-89. doi: $10.1159 / 000076456$

[6] Nodder D, Chappell B, Bates D, Freeman G, Hatch J, Keen J, et al. Multiple Sclerosis: Care needs for 2000 and beyond.
Journal of the Royal Society of Medicine. 2000; 93(5):219-24. PMCID: PMC1297995

[7] Ghanati E, Hadian M, Daghighi Asli AR. [Economic expenditures of multiple sclerosis medications and feasibility of providing health insurance policies for medications (Persian)]. Journal of Health Administration. 2011; 14(45):47-55.

[8] Ghaffari S, Fallahi Khoshknab M, Norouzi K, Mohammadi I. [Exploring Barriers of rehabilitation care in patients with multiple sclerosis: A qualitative study (Persian)]. Journal of Nursing \& Midwifery. 2014; 11(11):863-73.

[9] Amini R. [Health needs assessment methodology report in blind veterans (Persian)]. Iranian Journal of War \& Public Health. 2008; 1(3):45-54

[10] Epstein RM, Street RL. The values and value of patientcentered care. Annals of Family Medicine. 2011; 9(2):100-03 doi: $10.1370 /$ afm.1239

[11] Khan F, McPhail T, Brand C, Turner-Stokes L, Kilpatrick T. Ability profile and quality of life in an Australian community cohort. International Journal of Rehabilitation Research. 1999; 29(2):87-96. doi: 10.1097/01.mrr.0000194393.56772.62

[12] Burks JS, Bigley GK, Hill HH. Rehabilitation challenges in multiple sclerosis. Annals of Indian Academy of Neurology. 2009; 12(4):296-306. doi: 10.4103/0972-2327.58273

[13] Tsai LT, Lo FE, Yang CC, Keller JJ, Lyu SY. Gender differences in recreational sports participation among Taiwanese adults. International Journal of Environmental Research \& Public Health. 2015; 12(1): 829-40. doi: 10.3390/ ijerph120100829

[14] Forbes A, While A, Taylor M. What people with muly tiple sclerosis perceive to be important to meeting their needs. Journal of Advanced Nursing. 2007; 58(1):11-22. doi: 10.1111/j.1365-2648.2007.04219.x

[15] Borreani C, Bianchi E, Pietrolongo E, Rossi I, Cilia S, et al Unmet needs of people with severe multiple sclerosis and their carers: Qualitative findings for a home-based intervention. PLoS One. 2014; 9(10):e109679. doi: 10.1371/journal. pone. 0109679

[16] Koopman WJ, Benbow L, Vanadevoort M. Top 10 needs of people with multiple sclerosis and their significant others Journal of Neuroscience Nursing. 2006; 38(5):369-373. doi: 10.1097/01376517-200610000-00008

[17] Sajjadi H. [Multiple Sclerosis (M.S.): Epidemiologicresearch in 187 patients who admitted in university cnters of Tehran in 1998 (Persian)]. Rehabilitation Journal. 2001; 1(3):26-31

[18] Baraheni C, Bianchi E, Pietrolongo E, Rossi I, Cilia S, et al. Unmet Needs of People with Sever Multiple sclerosis and Thier Carers: Qualitative Findings For a Home_ Based Intervention . PLoS One.2014:10. Available From : http:// journals. Plus.org.Accessed March 26, 2015. 
